\title{
Current Treatment, Emerging Translational Therapies, and New Therapeutic Targets for Autoimmune Myasthenia Gravis
}

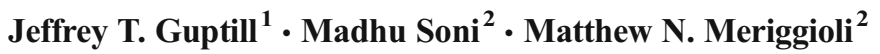

Published online: 28 October 2015

(C) The American Society for Experimental NeuroTherapeutics, Inc. 2015

\begin{abstract}
Myasthenia gravis (MG) is an autoimmune disease associated with the production of autoantibodies against 1) the skeletal muscle acetylcholine receptor; 2) muscle-specific kinase, a receptor tyrosine kinase critical for the maintenance of neuromuscular synapses; 3) low-density lipoprotein receptor-related protein 4 , an important molecular binding partner for muscle-specific kinase; and 4) other muscle endplate proteins. In addition to the profile of autoantibodies, MG may be classified according the location of the affected muscles (ocular vs generalized), the age of symptom onset, and the nature of thymic pathology. Immunopathologic events leading to the production of autoantibodies differ in the various disease subtypes. Advances in our knowledge of the immunopathogenesis of the subtypes of MG will allow for directed utilization of the ever-growing repertoire of therapeutic agents that target distinct nodes in the immune pathway relevant to the initiation and maintenance of autoimmune disease. In this review, we examine the pathogenesis of MG subtypes, current treatment options, and emerging new treatments and therapeutic targets.
\end{abstract}

Keywords Myasthenia gravis · Autoimmune ·

Neuromuscular junction $\cdot$ Immunomodulation

Matthew N. Meriggioli

matthew_meriggioli@rush.edu

1 Neuromuscular Division, Department of Neurology, Duke University Medical Center, Durham, NC, USA

2 Department of Neurological Sciences, Rush University Medical Center, Chicago, IL, USA

\section{Introduction}

Myasthenia gravis (MG) is an autoimmune disease caused by the production of antibodies to components of the muscle membrane at the neuromuscular junction. Recent evidence suggests that $\mathrm{MG}$ is both clinically and immunopathologically heterogeneous, consisting of subtypes with different primary immune targets, disease manifestations, and treatment responses $[1,2]$. In the most common type of MG, autoantibodies are produced that target the skeletal muscle acetylcholine receptor $(\mathrm{AChR})$, reducing the number of functional AChRs, and causing morphological damage to the endplate membrane, resulting in the clinical phenotype of fatigable muscle weakness [2]. The situation with AChR-associated MG becomes more complicated as there are clinical and immunological differences in patients with thymic abnormalities (thymic hyperplasia vs thymoma) versus no thymic pathology $[3,4]$. In the next most common form of MG, the immune target is the muscle-specific tyrosine kinase (MuSK), and the clinical disease, immunopathogenesis, and endplate pathology differ [5]. Other potential immune targets at the muscle endplate have been recently identified based on the presence of circulating antibodies. Importantly, treatment strategies appear to have varying efficacy in the various MG subtypes. While the disease usually responds to standard and nonspecific immunosuppression, current treatment paradigms frequently fail to control myasthenic weakness completely or are associated with significant morbidity because of the requirement for long-term immunosuppression. A better understanding of the immune derangements relevant for the particular MG subtypes and their respective specific immune pathway targets will be instrumental in developing new translational therapies that are more focused and therefore more effective and better tolerated. 


\section{MG Subtypes}

Autoimmune MG may be subdivided based on the profile of serum autoantibodies, the age of onset, the presence or absence of thymic pathology, and the distribution of clinical weakness (Table 1). The autoantibodies in MG target specific proteins of the postsynaptic muscle endplate (Fig. 1) causing a defect in neuromuscular transmission. The majority (approximately $85 \%$ ) of patients with MG have circulating antibodies targeting the skeletal muscle AChR. These antibodies are predominantly of the isotype IgG1 and IgG3 [6], and are directly pathogenic, binding to and resulting in the loss of functional AChRs by 3 primary mechanisms: focal lysis of the endplate membrane via activation of complement; crosslinking of adjacent receptors promoting internalization and degradation; and direct blockade of the acetylcholine binding site (Fig. 2) [7-10].

In AChR-positive MG, the production of autoantibodies by pathogenic B cells is T cell-dependent. Although anti-AChR antibodies directly contribute to the degradation of $\mathrm{AChR}$ at the neuromuscular junction, autoreactive $\mathrm{T}$ cells provide help to B cells that synthesize anti-AChR antibodies $[11,12]$. CD4+ T helper (Th) and T regulatory (Treg) cells recognize AChR epitopes in the context of major histocompatibility complex class II and exert a helper function on B cells to proliferate and differentiate into plasma cells.

Patients with anti-AChR-positive MG may be further subdivided into those with and without thymic pathology. Approximately $70 \%$ of patients with MG with anti-AChR antibodies have thymic follicular hyperplasia, approximately $10 \%$ have thymomas, and the remainder have a histologically normal or atrophic thymus gland $[4,13,14]$. The alterations of the immune system that occur with thymic hyperplasia versus thymoma are quite distinct.
In patients with thymic hyperplasia, there is evidence that the thymus is the primary site of immune sensitization to the AChR and may play a role in perpetuating the disease [15, 16]. Thymic follicular hyperplasia usually occurs in earlyonset MG and is characterized by the development of lymphoid germinal centers (GCs) containing a large number of B cells. The formation of these ectopic GCs may be triggered by a viral infection or other source of inflammation [17], but this has not been clearly demonstrated. GC formation is associated with an overexpression of proinflammatory cytokines and a chain of events including enhanced $\alpha$-AChR expression in thymic epithelial cells (TECs), recruitment of peripheral B cells, a dysfunction in Tregs, and, eventually, intrathymic autoantibody production [4]. Thus, the thymic GC environment in MG promotes the survival and differentiation of AChRspecific B cells and the production of antibodies $[16,18]$. In patients with MG, corticosteroid therapy reduces the size and number of GCs in the thymus [19]. If thymectomy is effective in disease modulation, its effects are most likely related to the removal of thymic GCs. Thus, other therapies that disrupt GCs may produce similar effects without the need for surgery. The persistence of disease in patients who do not appear to respond to thymectomy might be explained by the escape of autoreactive cells into the periphery.

Tumors originating from the TECs are called thymomas, and are found in about $10-15 \%$ of patients with MG [3, 4], usually in patients with generalized MG with disease onset when they are $>40$ years of age. These tumors commonly express self-antigens such as the AChR and the large muscle protein, titin. Naïve effector $\mathrm{T}$ cells with AChR or titin reactivity may escape negative selection due to the abnormal thymic microenvironment created by the thymoma [14]. Alternatively, autoimmunization may actually occur in the thymus owing to expression of $\mathrm{AChR}$ by the tumor and the

Table 1 Classification of myasthenia gravis (MG)

\begin{tabular}{|c|c|c|c|c|}
\hline Autoantibody target & Subtypes & Antibody isotypes & Thymic histology & Distinctive features \\
\hline \multirow[t]{4}{*}{$\mathrm{AChR}$} & Early onset & IgG1, IgG3 & Hyperplasia & Female predominance, favorable prognosis \\
\hline & Late onset & IgG1, IgG3 & Atrophy, normal & Antibodies to muscle antigens; may have severe course \\
\hline & Thymomatous & IgG1, IgG3 & Neoplasia & Antibodies to muscle antigens; other paraneoplastic disorders \\
\hline & Ocular & IgG1, IgG3 & $? ?$ & AChR Abs in $50 \%$ \\
\hline \multirow[t]{2}{*}{ Clustered AChR } & Generalized & IgG1 & May have hyperplasia & Clinical course similar to nonthymoma MG with AChR Abs \\
\hline & Ocular & IgG1 & $? ?$ & Similar to ocular subtype above \\
\hline MuSK & & IgG4 & Normal & $\begin{array}{l}\text { Selective oropharyngeal, facial, and respiratory weakness. } \\
\text { May have severe course. Poor response to cholinesterase } \\
\text { inhibitors and IVIg }\end{array}$ \\
\hline LRP4 & & IgG1 & $? ?$ & $\begin{array}{l}\text { Similar to AChR MG; favorable prognosis; may be seen } \\
\text { with AChR and MuSK Abs }\end{array}$ \\
\hline Other & $\begin{array}{l}\text { Agrin } \\
\text { Cortactin }\end{array}$ & $?$ & $? ?$ & May be found in patients with anti-AChR antibodies \\
\hline
\end{tabular}

$\mathrm{AChR}=$ acetylcholine receptor; $\mathrm{MuSK}=$ muscle-specific tyrosine kinase; $\mathrm{LRP} 4=$ low-density lipoprotein receptor-related protein $4 ;$ Abs $=$ antibodies; IVIg = intravenous immunoglobulin 


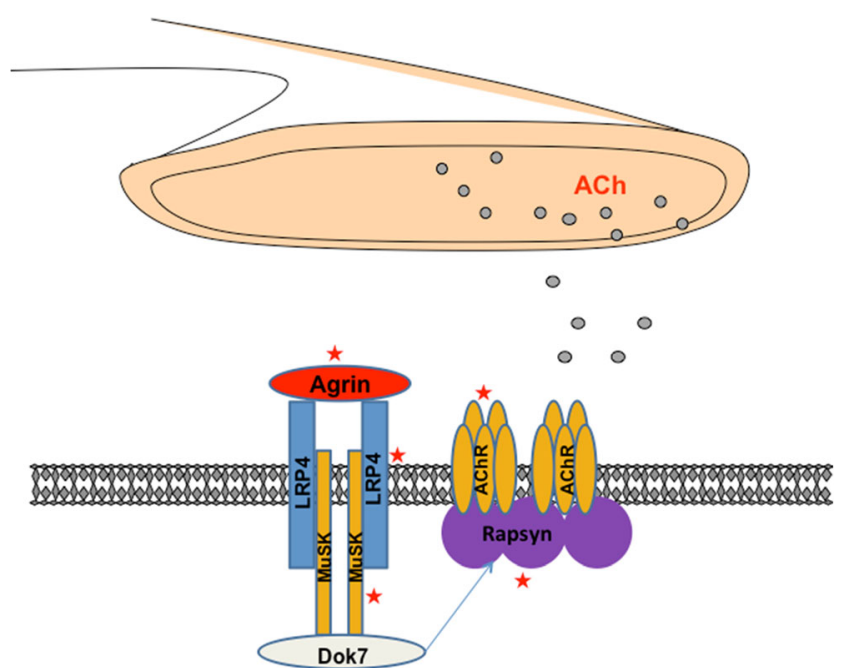

Fig. 1 The postsynaptic neuromuscular junction. Major components of the neuromuscular endplate are shown; antibodies to the designated proteins $(\star)$ have been described in autoimmune myasthenia gravis. $\mathrm{ACh}=$ acetylcholine; LRP4 $=$ low-density lipoprotein receptor-related protein 4; $\mathrm{MuSK}=$ muscle-specific tyrosine kinase; $\mathrm{AChR}=$ acetylcholine receptor

derangement of normal immune regulation due to a deficiency of AIRE (autoimmune regulator element; a transcriptional activator expressed by medullary TECs) [20]. In either case, there is export of potentially autoreactive or "primed" T cells that have the ability to stimulate a B-cell response in the periphery. Not surprisingly, the autoimmune response may be self-sustaining in these patients, persisting even after the tumor is removed.

MG associated with MuSK antibodies has unique clinical features such as prominent bulbar weakness, muscle atrophy, and relative sparing of ocular muscles [21]. The

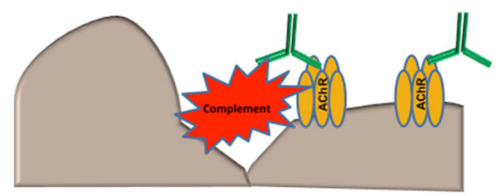

1. Complement mediated lysis of muscle endplate

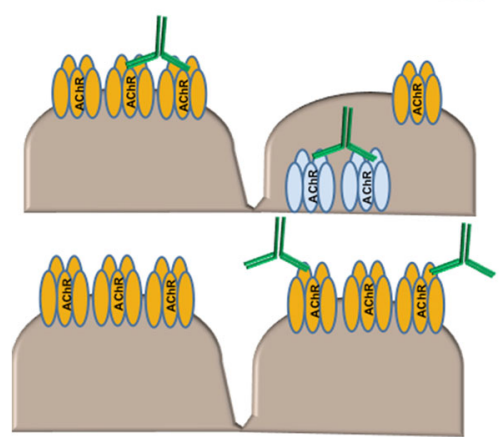

2. Cross-linkage and internalization of AChR (degradation)

3. Blocking of ACh binding site

Fig. 2 Three mechanisms of endplate pathology in acetylcholine receptor (AChR) myasthenia gravis. (1) Antibodies bind to AChR and activate complement leading to focal endplate lysis; (2) antibodies crosslink adjacent AChRs leading to internalization and degradation; (3) antibodies directly bind to acetyl choline (ACh) binding site blocking access to ACh immunopathology is also quite different. Most notably, the pathogenic antibodies are of the IgG4 isotype and disrupt the neuromuscular junction without the activation of complement, leading to perturbation of the agrin-MuSK-rapsynAChR pathway [5, 22]. IgG4 antibodies are dynamic molecules that undergo "half-antibody exchange" in vivo. As a result, most IgG4 molecules in the circulation comprise Fab arms with two different specificities ("bispecific") that form immune complexes and cannot cross-link antigens [23]. The trigger for the production of anti-MuSK IgG4 antibodies in MuSK MG is not known, and the role of T cells in the production of pathogenic anti-MuSK antibodies is incompletely investigated. Thymic pathology does not commonly occur in association with the disease [24]. The production of IgG4 antibodies in the setting of other immune responses appears to be driven, in part, by Th2 cytokines that mediate allergic responses [25], but $\mathrm{T}$ cells in patients with MuSK MG have increased frequencies of Th1 and Th17 cytokines [26]. B-cell immunopathology in MuSK MG includes elevated B-cell activating factor (BAFF) and lower frequencies of interleukin (IL)-10-producing regulatory B cells [27]. Reports of remarkable responses to B-cell depletion suggest that short-lived B-cell lineage cells (? plasmablasts) expressing CD20 may sustain the disease (see below).

There are accumulating reports describing circulating antibodies to other endplate proteins, including the low-density lipoprotein receptor-related protein-4 [28, 29], agrin [30], rapsyn [31], and most recently cortactin [32]. In many cases, these antibodies are seen in patients with anti-AChR or antiMuSK MG, so the definitive demonstration of their pathogenicity remains to be investigated. Finally, a subset of patients with MG who are seronegative for $\mathrm{AChR}$ antibodies using the conventional radioimmunoprecipitation assay have been shown to have antibodies binding to clustered AChR in a cell-based assay [33-35]. Early reports suggest these patients tend to have less severe disease but are otherwise similar to early-onset anti-AChR-positive MG, including the presence of thymic hyperplasia $[34,35]$.

\section{Present Management of Autoimmune MG}

Despite recent advances in immunology and immunotherapy, the current treatment of $\mathrm{MG}$ relies primarily on generalized and nonspecific immunosuppression. Nevertheless, MG is one of the more treatable neurologic conditions, and most patients respond favorably to treatment [36]. However, high doses of corticosteroids are often needed to induce remission of disease and chronic treatment with immunosuppressive drugs is usually required to maintain disease control. The general management approach for MG includes early recognition, prompt treatment, support of bulbar/respiratory function, symptomatic treatment by pharmacologic enhancement of 
neuromuscular transmission, and immunotherapy. Treatment regimens should be individualized based on disease subtype and should take into account autoantibody status, thymic pathology, age, comorbidities, and disease severity. General treatment options include symptomatic therapy, rapid-acting or short-term immunomodulation, and long-term immunosuppression or thymectomy.

The first-line symptomatic treatment for AChR antibodypositive patients is the acetylcholinesterase inhibitor pyridostigmine. Cholinesterase inhibitors provide temporary relief of symptoms but do not induce complete or sustained relief of MG symptoms in most patients and do not affect disease progression. They may be sufficient for management of patients with nonprogressive mild or purely ocular disease. Patients with MuSK MG may not respond to pyridostigmine and higher doses may actually lead to increased weakness, thought to be due to desensitization of AChRs [37].

As with many treatments in $\mathrm{MG}$, support for the use of corticosteroids is largely limited to retrospective series. Based on the available evidence, approximately $70-75 \%$ of patients treated with prednisone achieved either marked improvement or remission [38-40]. Prednisone is generally used when symptoms of MG are not adequately controlled by cholinesterase inhibitors alone. Prednisone is usually administered at high doses $(0.75-1.0 \mathrm{mg} / \mathrm{kg} /$ day $)$ for several months during the initial treatment of moderate or severe MG, and then gradually tapered or continued at low (often alternate day) doses for many years. Lower initial doses may be used in milder or predominantly ocular MG. A clinical response is usually evident in 2-3 weeks. Transient worsening of weakness has been reported to occur in approximately a third to half of patients treated with high-dose daily prednisone [41]. Therefore, hospitalization or administration of plasma exchange (PLEX) or intravenous immunoglobulin (IVIg) during steroid initiation is advised in the setting of significant oropharyngeal or respiratory symptoms.

Several immunosuppressant drugs are effective in $\mathrm{MG}$ (Table 2). Azathioprine (AZA) is a purine antimetabolite that interferes with $\mathrm{T}$ - and B-cell proliferation, and is the immunosuppressant drug with the longest track record in MG. It improves weakness in most patients but benefit may not be apparent for 6-12 months. A prospective randomized study showed that the addition of AZA to prednisolone significantly reduced the dose of prednisolone required to maintain remission and reduced the number of treatment failures [42].

Other immunosuppressant drugs used as steroid-sparing drugs in MG include mycophenolate mofetil, ciclosporin, methotrexate, and tacrolimus [43]. In general, these drugs are used in combination with corticosteroids with the intention of improving disease control so that the steroids may be reduced or discontinued. Mycophenolate mofetil may be chosen over AZA because of its favorable side effect profile; the others are mainly used when AZA is ineffective or poorly tolerated. Effectiveness and tolerability are variable and patient compliance may be suboptimal.

Effective use of immunosuppressants in MG requires a long-term commitment - few patients maintain improvement unless therapy is continued at effective doses. The long-term risk of malignancy is not established, but there are reports of an increased occurrence of malignancy in patients with $\mathrm{MG}$ and other autoimmune diseases receiving immunosuppression $[44,45]$, so the minimal dose of immunosuppressant medications required to maintain control of the disease should be used.

IVIg and PLEX are used for acute severe exacerbations in generalized MG, to optimize strength before surgery or for rapid short-term immunotherapy. PLEX effectively improves strength in most patients with severe MG [46, 47]. IVIg is widely used for patients with exacerbating MG. Randomized controlled trials that show efficacy similar to PLEX [46], and a double-blind, placebo-controlled trial in patients with MG with worsening weakness [48], support its use in the clinic. Randomized controlled trials comparing IVIg with plasmapheresis have shown no significant differences between the two in treatment of an acute MG exacerbation [49], but PLEX may have a faster onset of action and is the treatment of choice in MG crisis.

The absolute indication for thymectomy is the presence of a thymoma, owing to the risk of local invasion and its malignant potential; however, removal of the tumor often does not lead to remission or even improvement. Patients with thymomatous MG tend to have more severe disease [50], and aggressive immunotherapy is usually required and should be carefully tapered after thymectomy. Anti-T-cell agents such as tacrolimus or ciclosporin may be more effective in these patients, as the disease is likely maintained by autoreactive $\mathrm{T}$ cells.

Thymectomy in nonthymomatous MG is usually considered a therapeutic option in anti-AChR-positive, generalized MG with disease onset before the age of 50 years, and some would also recommend it in patients who lack anti-AChR antibodies. A meta-analysis concluded that thymectomy was likely beneficial, and that it should be considered as a treatment option in selected patients with MG [51]. An international, randomized trial of thymectomy in nonthymomatous MG is being completed (NCT00294658), and will hopefully clarify this issue.

Most of the accumulated experience with treatment modalities in MG come from AChR-positive disease. In MuSK MG, there are a few important differences. As noted above, patients with MuSK MG often do not respond or may actually worsen with oral anticholinesterase drugs. There is often a remarkable response to PLEX, while the response to IVIg is often more modest [21]. Anti-MuSK antibody titers appear to correlate with severity of disease and response to immunotherapy [52, 53]. In contrast, $\mathrm{AChR}$ antibody titers do not reliably predict 
Table 2 Immune-modulating agents used in myasthenia gravis (MG)

\begin{tabular}{|c|c|c|c|c|}
\hline Treatment & Initial dosing/frequency & Onset of action & Monitor & Comments \\
\hline PLEX & 4-6 exchanges on alternate days & $1-5$ days & $\begin{array}{l}\text { BP, volume status, coagulation } \\
\text { parameters }\end{array}$ & $\begin{array}{l}\text { Use in exacerbating MG; treatment } \\
\text { of choice in myasthenic crisis }\end{array}$ \\
\hline IVIg & $1-2 \mathrm{~g} / \mathrm{kg}$ (over $2-5$ days) & $3-10$ days & $\mathrm{BP}$, renal/cardiac status & Use in exacerbating $\mathrm{MG}$ \\
\hline Prednisone & $\begin{array}{l}\text { a) } 0.75-1.00 \mathrm{mg} / \mathrm{kg} / \text { day } \\
\text { b) } 20-40 \mathrm{mg} / \text { day for mild or } \\
\text { ocular MG }\end{array}$ & 3-6 weeks & $\mathrm{BP}$, glucose, bone density & $\begin{array}{l}\text { First-line immune therapy; short-term } \\
\text { use of high doses; frequent side effects }\end{array}$ \\
\hline AZA & $2-3 \mathrm{mg} / \mathrm{kg} /$ day & 6-12 months & $\mathrm{CBC}$, liver function & First-line steroid-sparing drug \\
\hline MMF & $\begin{array}{l}2.0-2.5 \mathrm{~g} / \text { day in divided } \\
\text { twice daily doses }\end{array}$ & 4-12 months & $\mathrm{CBC}$ & $\begin{array}{l}\text { First-line steroid-sparing; widely used } \\
\text { in USA. Less toxic than AZA }\end{array}$ \\
\hline CyA & $\begin{array}{l}\text { 4-6 mg/kg/day in divided } \\
\text { twice-daily doses }\end{array}$ & $2-3$ months & Renal function, BP & $\begin{array}{l}\text { Steroid-sparing in patients intolerant } \\
\text { or unresponsive to AZA or MMF }\end{array}$ \\
\hline Tacrolimus & $3-5 \mathrm{mg} /$ day & 4-8 weeks & $\begin{array}{l}\text { Renal function, potassium, } \\
\text { BP, tacrolimus levels }\end{array}$ & $\begin{array}{l}\text { Steroid-sparing in patients intolerant } \\
\text { or unresponsive to AZA, MMF, or CyA. } \\
\text { Thymomatous MG }\end{array}$ \\
\hline Cyclophosphamide & $\begin{array}{l}\text { a) } 500 \mathrm{mg} / \mathrm{m}^{2} \\
\text { b) } 50 \mathrm{mg} / \mathrm{kg} \times 4\end{array}$ & 2-4 weeks & $\mathrm{CBC}$, platelet, urine & Use in refractory/severe MG \\
\hline MTX & $7.5-25.0 \mathrm{mg}$ weekly & $1-3$ months & $\begin{array}{l}\mathrm{CBC} \text {, renal/liver function, } \\
\text { CXR }\end{array}$ & Similar efficacy and tolerability to AZA \\
\hline
\end{tabular}

PLEX = plasma exchange; IVIg = intravenous immunoglobulin; $\mathrm{AZA}=$ azathioprine; $\mathrm{MMF}=$ mycophenolate mofetil $; \mathrm{CyA}=\mathrm{ciclosporin} ; \mathrm{BP}=\mathrm{blood}$ pressure; $\mathrm{CBC}=$ complete blood count $\mathrm{CXR}=$ chest $\mathrm{X}$-ray

disease severity in individual patients [2]. While experience is limited, lipoprotein receptor-related protein-4-associated patients appear to be clinically similar to AChR-positive patients [54], but currently there is no clear role for thymectomy.

\section{Emerging Therapies and New Therapeutic Targets}

There is a need to identify new therapeutic agents and targets for the treatment of $\mathrm{MG}$, with the goal of improved, more focused treatment and fewer adverse events. A working knowledge of the immunopathogenesis of $M G$ is required to identify specific immune targets relevant to the development and maintenance of MG (Fig. 3). A few of the more promising approaches with compounds currently being tested in the clinic include targeting of T-cell signaling, B cells, and B-cell trophic factors, cytokine-cytokine receptor targeting, and complement inhibition. Other strategies with therapeutic potential based on experimental MG models include vaccination approaches, Fc receptor modulation, targeting B cell-T cell interactions, and targeting tissue-specific factors to enhance endplate regeneration.

\section{T-cell Signaling Pathways and Tregs}

Targeting of T-cell co-stimulatory and co-inhibitory pathways has become a major therapeutic strategy in the immunotherapy of autoimmune diseases, organ transplantation, and cancer [55]. T-cell responsiveness is determined by the recognition of a specific complex of peptide-major histocompatibility complex by the T-cell receptor in combination with engagement of co-signaling pathways that promote or inhibit T-cell activation, thereby fine-tuning the T-cell response [56]. CD28 (T cell-specific surface glycoprotein CD28) is the primary costimulatory molecule for CD4+ helper $\mathrm{T}$ cells and binds the CD80 (B7-1) and CD86 (B7-2) ligands that are expressed on antigen presenting cells (APCs), including B cells [57, 58]. CD28 co-stimulation increases T-cell responses in naïve cells by increasing cytokine production, mainly of IL-2, which binds to CD25 on T cells and promotes proliferation. CTLA4 (cytotoxic T-lymphocyte protein 4 (CTLA-4) is a coinhibitory molecule expressed on CD4+ T cells upon activation, which also binds CD80 and CD86, and plays a critical role in the downregulation of antigen-activated immune responses [57].

This pathway can be blocked using an immunoglobulin fusion protein, CTLA-4-Ig (abatacept), which binds to $\mathrm{CD} 80 / \mathrm{CD} 86$ and blocks both activating (CD28) and inhibitory signals (CTLA-4). Abatacept has been tested in the clinic and has been shown to be effective and safe, and is currently used for treatment of rheumatoid arthritis (RA) [59]; however, importantly, it failed to show efficacy in early-phase trials in multiple sclerosis (MS) and ulcerative colitis [60, 61]. This highlights the evolving concept that co-stimulation blockade with abatacept has differential effects, depending upon the type of T-cell response (effective for Th1 responses but perhaps not for Th2 or Th17-mediated disease).

As noted, there is evidence that AChR-associated MG is primarily mediated by Th1 T-cell responses, although there is 


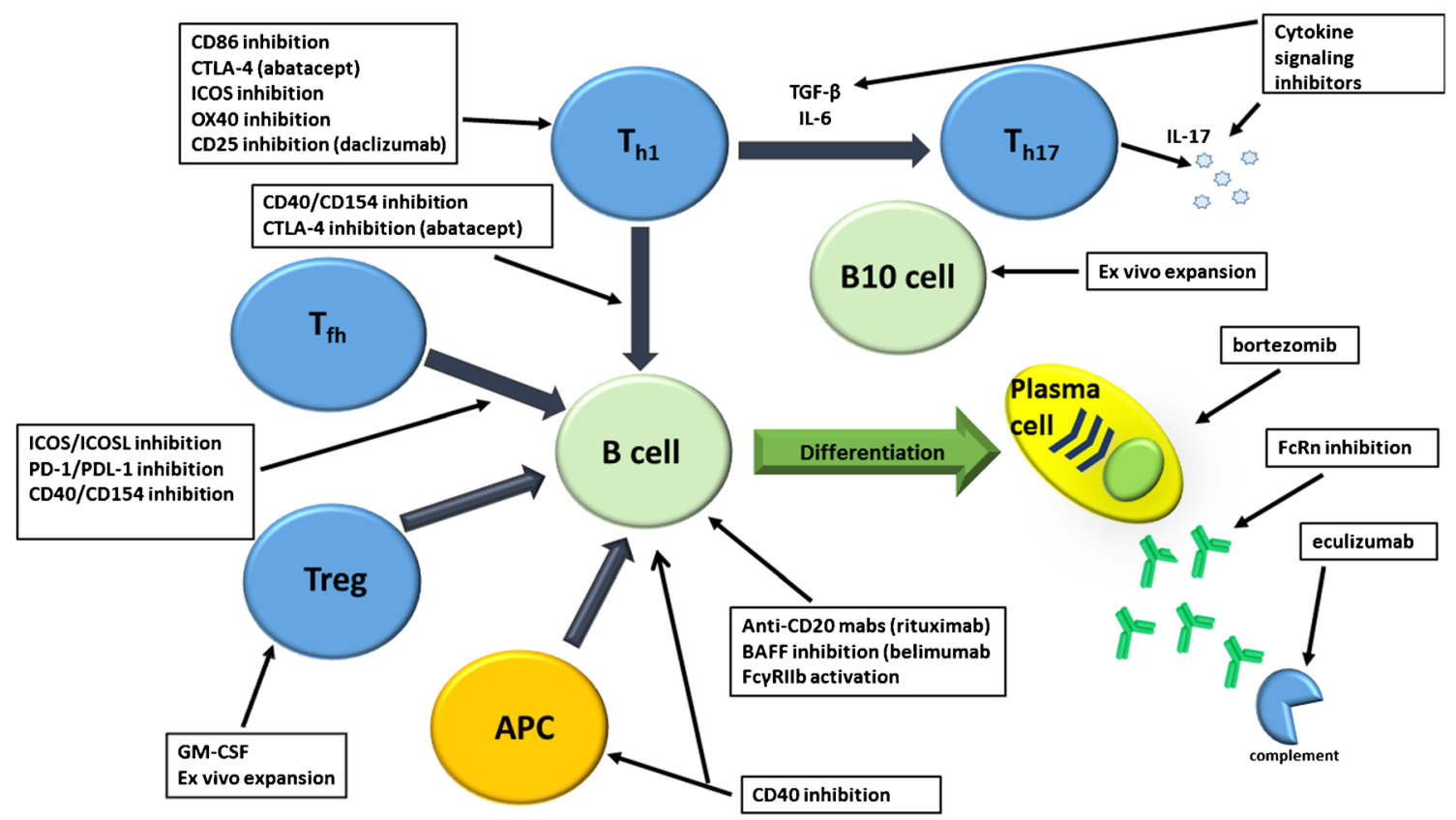

Fig. 3 Immunotherapeutic targets for the treatment of myasthenia gravis (MG). Targets for MG therapy are shown as they impact the immunopathogenesis of the disease. Therapeutic agents can target antigen-presenting cells (APCs), T cells, T-cell signaling, $\mathrm{T}$ regulatory cells (Treg) cells, B cells, B-cell signaling, plasma cells, or downstream effector molecules (antibodies and complement). CTLA- $4=$ cytotoxic T-

recent evidence of the involvement of IL-17-producing T cells as well $[26,62,63]$. There is additional evidence that CTLA-4 expression on T cells may be altered in MG [64]. Furthermore, a recent genome-wide association study in patients with AChR-positive MG identified an association signal at the CTLA-4 gene, suggesting that aberrant cellular mechanisms involving CTLA-4 may predispose to MG and that therapies targeting this pathway should be considered [65]. The above findings also suggest that there are genetically defined patients with MG that may be differentially responsive to abatacept or other related compounds.

Upon activation, $\mathrm{T}$ cells express another co-stimulatory molecule referred to as the inducible $\mathrm{T}$ cell co-stimulator protein (ICOS), which, upon binding to the ICOS-ligand on APCs, further enhances T-cell activation and regulates both $\mathrm{T}$ - and B-cell responses [66]. ICOS is necessary for the development of experimental MG [67], and its inhibition can ameliorate autoimmunity, including in diseases in which autoantibodies are produced [68], suggesting that this may be a useful strategy in MG. Another co-stimulatory molecule induced upon T-cell activation is OX40, which binds to OX40L on the APC and enhances cytokine production, proliferation, and survival of T cells [69]. There is also accumulating evidence that the OX40-OX40L pathway controls the suppressive ability of Tregs [70], and that OX40L expressed on dendritic cells can selectively expand Tregs [71]. Thus, targeting the OX40OX40L pathway could be further investigated in MG. lymphocyte protein 4 ; ICOS = inducible T cell co-stimulatory protein; $\mathrm{T}_{\mathrm{fh}}$ $=\mathrm{T}$ follicular helper cell; PD-1 = programmed cell death 1 ; PDL-1 = programmed cell death ligand $1 ; \mathrm{GM}-\mathrm{CSF}=$ granulocyte macrophage colony-stimulating factor; $\mathrm{T}_{\mathrm{h}}=\mathrm{T}$ helper cell; TGF- $\beta=$ transforming growth factor- $\beta$; IL- $6=$ interleukin- 6 ; BAFF $=$ B-cell activating factor; IL-17 = interleukin-17; FcRn $=$ neonatal Fc receptor

Daclizumab is a monoclonal antibody that binds to CD25 thereby antagonizing the activating effects of IL-2 on T cells. This compound, originally developed for the treatment of leukemia, has been shown to be relatively well-tolerated and effective in MS [72]. However, IL-2 is critical to the production and function of Tregs, and daclizumab may potentially inhibit the function of these cells. Daclizumab may be considered for study in MG, but the potential for a deleterious effect due to an exacerbation of known Treg dysfunction in $\mathrm{MG}$ needs to be carefully contemplated.

A subset of T cells, CD4+CD25+ Tregs, plays a crucial role in maintenance of immune homeostasis against self-antigens [73], as evidenced by individuals with mutations in forkhead box P3 (FOXP3), a transcription factor necessary for Treg differentiation and maintenance $[73,74]$. In humans, a lack of functional Tregs leads to autoimmunity. An extension of these observations is that defects in Treg number or function may underlie the development of human autoimmune disorders. Importantly, Tregs have been implicated in preventing autoantibody production by self-reactive B cells [75-77], and dysfunction or deficiencies of Tregs have been demonstrated in MG [63, 78-81].

The above findings suggest that therapies targeting Tregs have the potential to overcome autoimmune conditions (like MG) effectively. There are several agents [i.e., rapamycin, vitamin $\mathrm{D}$ analogues, granulocyte macrophage colonystimulating factor (GM-CSF); see below] that could be used 
to improve the function or enhance the numbers of Tregs [82, 83]. In addition, a number of currently used immunomodulatory treatments for MG, including corticosteroids and IVIg [84-86], have been reported to induce an expansion of Tregs and/or an enhancement in Treg function. A fuller understanding of the mechanisms underlying these effects may be helpful in identifying novel treatment strategies. The idea of cellular therapy involving the adoptive transfer of expanded and/or enhanced Tregs has the potential to offer a very desirable and targeted therapy. A limitation that prevents therapeutic utilization of Tregs in autoimmune diseases is the relative difficulty in obtaining large numbers of Tregs. Activation of known co-stimulatory pathways such as the OX40-OX40L pathway, as well as cytokines and growth factors (see below), may allow for enhanced expansion of functional Tregs ex vivo, which can then be adoptively transferred as a potential therapy for human autoimmunity.

\section{T cell-B cell Interactions}

CD40 is expressed on APCs, including macrophages and dendritic cells, as well as B cells [87]. The ligand for CD40, CD154, or CD40L is expressed on activated T cells. Powerful modulation of autoimmune responses can be achieved through targeting of the CD40-CD154 (CD40 ligand) pathway. CD154-induced activation of B cells induces immunoglobulin class switch, antibody-secreting cell differentiation, as well as GC formation [87]. Treatment with anti-CD154 antibodies has been shown to suppress experimental MG and lead to a decrease in the AChR-specific humoral response [88]. The cytokine profile of treated rats suggests that the underlying mechanism involved downregulation of AChRspecific Th1-regulated responses with no significant effect on Th2- and Th3-regulated AChR-specific responses [88]. Owing to the occurrence of thromboembolic events in treated subjects, development of several humanized anti-CD154 monoclonal antibodies has been stalled in early clinical trials [89]. Subsequent studies have shown that CD154 functions as a stabilizer of arterial thrombi in a CD40 independent manner [90], suggesting that targeting CD40 may allow for an immune-modulatory effect without affecting blood clotting.

Along these lines, several anti-CD40 monoclonal antibodies have undergone early clinical trials for B cell-related malignancy and autoimmunity, with favorable results in terms of safety and tolerability [91, 92]. As noted, the anti-AChR autoimmune response in $\mathrm{MG}$ is $\mathrm{T}$ cell-dependent, suggesting that disrupting CD40-CD154 signaling may be beneficial. In addition, CD40-CD154 signaling is essential in the formation of GCs and if the perceived therapeutic benefit of thymectomy in MG with thymic hyperplasia is due to the removal of ectopic GCs, blocking CD40 may potentially allow for GC disruption prior to or even without surgical removal of the gland [93]. However, in thymoma-associated MG, thymoma- derived autoreactive $\mathrm{T}$ cells are released into the peripheral Tcell repertoire and become self-perpetuating even after removal of the thymoma, likely due to interactions with $\mathrm{B}$ cells in the peripheral lymphoid organs. These interactions could be potentially targeted through disruption of CD40-CD154 signaling as well.

There is evidence that both Th1 and Th17 T cells are involved and necessary for the AChR-specific B-cell responses in MG associated with anti-AChR antibodies [63, 94]. Therefore, targeting these cells would make the most sense in this MG subset but perhaps may not be effective in MuSKpositive MG, where the role of T-cell interaction with antibody-producing B cells, and the specific subset of T cells involved, is not as well characterized. However, one possible explanation for the robust response to B-cell depletion in MuSK MG is that short-lived, anti-MuSK antibody-producing plasmablasts are eliminated, and if this is true, targeting CD40 may also be effective in MuSK MG as CD40 signaling is required for B-cell differentiation into plasmablasts [87].

Finally, there is growing interest in the role of $\mathrm{T}$ follicular helper (TFH) cells in providing B cells help during an immune response, and emerging evidence that the dysfunction of TFH cells potentially plays a role in autoimmunity by positive selection of autoreactive B cells [95]. An increased frequency of circulating "counterparts" of TFH cells has been observed in patients with MG, correlating with levels of anti-AChR antibodies [96]. Important interactions of TFH cells and B cells occur through the ICOS-ICOS ligand, programmed cell death-1, and programmed cell death ligand-1, and CD40$\mathrm{CD} 154$, all of which may be targeted as noted above.

\section{B Cells, B-cell Trophic Factors, and Plasma Cells}

B cells are critical for the pathogenesis of all forms of autoimmune MG. Evidence from uncontrolled and/or observational studies suggests that B-cell depletion with rituximab may be an effective intervention in refractory $\mathrm{MG}$, both for antiAChR and anti-MuSK-positive disease [21, 97-100]. A controlled clinical trial of rituximab in anti-AChR MG is currently ongoing (NCT02110706). Second-generation anti-CD20 monoclonal antibodies that are fully humanized and with enhanced effector functions will also likely be tried in MG in the future [101, 102]. Targeting B cells may provide benefit in MG not only by reducing the numbers of antibodyproducing cells (the likely mechanism in anti-MuSK MG), but also by modulating other B-cell functions, including antigen presentation and cytokine production. Recently, a subset of B cells called regulatory B cells, or B10 cells, have been characterized based on their production of IL-10 and have been shown to function in the suppression of B-cell responses [103]. In addition, it has been shown that patients with MG may have fewer circulating B10 cells than healthy controls, appearing to correlate with disease severity, and that patients 
responding to B-cell depletion with rituximab exhibit more rapid re-population of circulating B10 cells [104], suggesting a potential mechanism for the therapeutic effect. Future clinical studies of B cell-depleting agents should be accompanied by a thorough investigation of the immune response, including the $\mathrm{B}$ regulatory cell subset, assessing anti-AChR disease versus anti-MuSK disease and the associated changes in this $\mathrm{B}$ cell subset in response to B-cell depletion.

BAFF is a potent survival factor for B cells and plays an important role in their proliferation and differentiation [105]. Studies have shown that serum levels of BAFF are elevated in patients with AChR and MuSK MG, and that these levels may be particularly elevated in patients with active anti-AChRpositive disease [106, 107]. A human monoclonal antibody targeting BAFF, belimumab, has been approved for the treatment of lupus erythematosus [108]. Belimumab binds to soluble BAFF, rather than membrane-bound BAFF on B cells, and reduces $\mathrm{B}$-cell activation and differentiation into antibody-producing plasma cells. B cell numbers are also reduced but not nearly to the extent observed with anti-CD20 monoclonal antibodies, such as rituximab. An international, phase II study of belimumab to assess its efficacy in patients with AChR and MuSK MG with generalized disease is ongoing (NCT01480596). Other compounds targeting B cells or Bcell trophic factors are in development for autoimmune disease and could be also be investigated in MG [109].

Autoreactive memory plasma cells may contribute to the maintenance of autoimmunity in MG. Plasma cells predominantly reside in bone marrow and secondary lymphoid organs, rather than the peripheral circulation [110]. Thus, they are rare in the peripheral blood and relatively sequestered from tissue compartments available to therapeutics. Although not completely defined in $\mathrm{MG}$, it is likely that plasma cells are resistant to most current oral therapies and that the gradual improvements observed with oral immunosuppressives may be reflected by this resistance and the slow impact on plasma cell populations. Recent experience with rituximab seems to suggest that 2 distinct populations of plasma cells have an immunopathological significance in AChR and MuSK MG. Rituximab treatment results in obvious lowering of MuSK autoantibody titers, whereas AChR autoantibody titers remain relatively unchanged [98]. This suggests that activated B cells, which express CD20, are the predominant source of shortlived plasma cells producing MuSK autoantibodies. The activated B cells are destroyed by rituximab in MuSK MG, leading to gradual reductions in plasma cells and autoantibodies and the dramatic clinical improvements often observed. In contrast, the current data showing that patients with $\mathrm{AChR}$ MG do not have as robust clinical responses to rituximab may be explained by autoantibodies produced predominantly by long-lived, protected, plasma cells. Thus, a strategy specifically targeting depletion of plasma cells may result in faster clinical improvements, either alone or as an induction strategy in combination with other immunosuppressive drug used to control the disease.

Bortezomib is a small-molecule proteasome inhibitor indicated for the treatment of patients with multiple myeloma and mantle cell lymphoma [111, 112]. By inhibiting proteasome activity in plasma cells, bortezomib disrupts proteolytic pathways leading to protein accumulation within plasma cells and ultimately cell death. It has been studied in animal models of autoimmunity, such as lupus and vasculitis, and has been shown to reduce autoantibody titers and improve clinical outcomes [113]. In experimental MG, bortezomib reduced antiAChR antibody titers, inhibited damage to the postsynaptic muscle membrane, and resulted in clinical improvement [114]. In cultures from thymus from patients with $\mathrm{MG}$, bortezomib rapidly halted autoantibody production and depleted plasma cells [115].

In patients with cancer, a prominent adverse effect caused by bortezomib is a sensory greater than motor peripheral neuropathy (about a third of patients). This potentially limiting adverse effect, which may be acceptable for patients with cancer, has mitigated enthusiasm for its use in autoimmunity. However, lower dosing regimens and less frequent or subcutaneous administration may reduce the incidence and severity of toxic neuropathy while still allowing for effective treatment of MG $[116,117]$. The toxicity of these agents is clearly a limitation; however, next-generation proteasome inhibitors may provide a safe option for urgent treatment of severe MG.

\section{Fc Receptor Modulation}

Fc receptors are key players in the humoral and cellular immune response through their interactions with $\mathrm{IgG}$, and have emerged as viable targets in the treatment of autoimmune disease. Antibodies of the IgG isotype interact with the immune system via $\mathrm{Fc} \gamma$ receptors expressed on immune cells, including B cells [118]. These interactions can provide both positive and negative regulatory signals and serve to modulate the immune response. Positive signaling occurs via a number of $\mathrm{Fc} \gamma \mathrm{R}$,s which have varying affinities for IgG Fc based on the IgG isotype [118]. Negative signals are mediated through the inhibitory Fc $\gamma$ RIIb expressed on B cells, which upon engagement suppress $\mathrm{B}$-cell activation. The neonatal $\mathrm{Fc}$ receptor ( FcRn) functions as a chaperone for IgG in the adult, protecting it from catabolism and aiding its transfer into various cells [118].

IVIg is known to have an effect on Fc receptors, and there is evidence that the therapeutic effect may be affected by the degree and type (sialylation) of glycosylation of Fc core IgG molecules. Engineering IVIg preparations to enrich for sialylation, for example, may enhance efficacy in autoimmune disease [119]. The effect of IVIg in MG and other autoimmune conditions has been attributed to the $\mathrm{IgG} \mathrm{Fc}$ domains, likely through interaction with $\mathrm{Fc} \gamma$ receptors [120]. Along 
these lines, recombinant multimeric Fc molecules have been shown to have modulatory effects on the clinical course of experimental MG [121]. The beneficial clinical effects were accompanied by downmodulation of autoantibody responses, reduced B-cell activation, an expansion in FoxP3+ Tregs, and a significant increase in surface expression of the inhibitory Fc $\gamma$ RIIB protein [121]. The advantages of this approach over IVIg would be a reduced volume load, enhanced availability, and potentially reduced infection risk.

Given its established role in the regulation of IgG metabolism, there is interest in targeting FcRn-IgG interactions as a strategy to lower endogenous IgG levels [122]. An FcRnspecific monoclonal antibody has been studied in passive and active models of rat experimental $\mathrm{MG}$ and shown to ameliorate symptoms and lower autoantibody levels [123]. Finally, another promising approach is the design of bispecific ligands targeting the inhibitory Fc $\gamma$ RIIb and the B-cell receptor. Recently, a bispecific antibody (XmAb5871) was designed to bind the Fc $\gamma$ RIIb via its Fc domain and also bind CD19 through a humanized Fv region. This antibody showed a potent inhibitory effect on suppressing humoral immune responses in humanized mouse models [124].

\section{Complement Inhibition}

Eculizumab is a humanized monoclonal IgG antibody against C5 complement [125]. Complement is a component of the innate immune system that assists antibodies and phagocytes in clearing pathogens. In several autoimmune diseases, the interaction between complement and autoantibodies likely contributes to tissue damage. By binding to $\mathrm{C} 5$, eculizumab prevents cleavage to $\mathrm{C} 5 \mathrm{a}$ and $\mathrm{C} 5 \mathrm{~b}$ and the generation of the terminal membrane attack complex (C5b-9). It is currently indicated for 2 rare diseases, paroxysmal nocturnal hemoglobinuria and atypical hemolytic uremic syndrome [125].

Pathology studies have demonstrated complement deposition in the motor endplate region in AChR MG [126-128]. In addition, the autoantibodies in AChR MG are predominantly IgG1 and IgG3, which are known to activate complement $[129,130]$. This knowledge provided part of the rationale for a placebo-controlled phase II crossover study of eculizumab conducted in patients with refractory MG, to determine safety and whether complement inhibition could ameliorate the disease, likely through minimizing complementmediated damage at the muscle endplate. After enrolling 14 patients, the trial was stopped early owing to slow recruitment. Nonetheless, the study demonstrated that eculizumab was well tolerated and significant reductions in quantitative $\mathrm{MG}$ scores were observed during eculizumab treatment [131].

\section{Cytokine, Cytokine Receptors, and Growth Factors}

There is evidence that both Th1 and Th2 cytokines are involved in the pathogenesis of MG, and the relative contribution of each type of immune reaction likely differs for the particular MG subtype and probably for various stages of disease. Targeting Th1 cytokines such as IL-12 and tumor necrosis factor- $\alpha$ have produced promising results in experimental models but, owing to safety issues, have been difficult to apply in the clinic. As noted, accumulating evidence suggests that Th17 immune reactions play an important role in MG, and cytokines such as IL-17 and IL-6 may represent attractive therapeutic targets. Several human monoclonal antibodies directed against IL-17 are in development, including brodalumab (AMG 827), ixekizumab (LY2439821), and secukinumab (Cosentyx; Novartis, Basel, Switzerland). Clinical development of these humanized monoclonal antibodies has focused on psoriasis, where they have been shown to be effective [132, 133]. The contribution of IL-6 in MG is suggested by its activity as a promoter of B-cell differentiation and proliferation and in the induction of B-cell maturation into antibody-producing plasma cells [134]. IL- ${ }^{-/-}$mice were found to be resistant to the induction of experimental MG [135], and blocking IL-6 by administration of anti-IL-6 antibodies suppresses experimental MG [136]. Suppression of disease was accompanied by a decrease in the overall anti-AChR antibody titer and by a reduced number of $\mathrm{B}$ cells compared with control treatment. Additionally, toclizumab, a humanized monoclonal antibody targeting the IL- 6 receptor, is on the market with established efficacy in RA and systemic lupus erthyematosus, as well as early promising results in neuromyelitis optica [137-139]. Other agents targeting IL-6/IL-6R are being developed and would offer potential efficacy in MG.

GM-CSF is a cytokine acting as an important hematopoietic growth factor and immune modulator that has a profound effect on various circulating immune cells. Its effects on dendritic cell maturation and the enhancement of Treg function have been studied in the context of various autoimmune models [140]. GM-CSF has been shown to ameliorate experimental MG [141-143], and to enhance the in vitro suppressive function of isolated Tregs from patients with MG [144], possibly by upregulating FOXP3 expression in these cells. In a patient severely affected with MG who failed aggressive immunotherapy, treatment with GM-CSF resulted in increased FOXP3 expression in Tregs and improved ex vivo Treg-mediated suppression of T-cell proliferation following polyclonal or AChR-specific stimulation [145]. A pilot study to further assess the safety of GM-CSF in patients with MG would likely be the next step towards potentially expanding its use in patients. 


\section{Vaccination Approaches}

The idea of tolerizing the immune system to the AChR by administering AChR peptides orally or nasally has been investigated in experimental MG models [146, 147], but has been difficult to translate in the clinic. DNA vaccinations have also been proposed, but, as with peptide vaccines, a primary concern is the potential for exacerbation of the anti-AChR immune response. Recently, immunization with AChR cytoplasmic domains in adjuvant has been proposed as a promising antigen-specific therapeutic approach to MG [148]. As the cytoplasmic AChR epitopes are not expressed extracellularly and would not be accessible to the immune system, this approach may circumvent concerns regarding disease exacerbation. The mechanism of this approach in experimental models remains to be determined prior to application to the human disease.

\section{Autologous Stem Cell Transplantation}

The strategy of autologous stem cell transplantation as a therapeutic approach for refractory autoimmune disease is based on the idea that the transplanted immune cells will be "reset" and free of autoimmune reactivity. This approach has been tried in a number of conditions, including MS, systemic sclerosis, systemic lupus erythematosus, RA, juvenile idiopathic arthritis, and immune cytopenias [149]. Reports suggest that patients have experienced long-term disease-free remissions and immune reconstitution studies have shown a resetting of the immune system. Treatment-related mortality and morbidity have been reduced in recent years but remains a concern. A trial of hematopoietic stem cell therapy in patients with $\mathrm{MG}$ is ongoing but not currently recruiting patients (NCT00424489).

\section{Endplate-specific Factors and Muscle Contractility}

An adjunctive approach to the treatment of $\mathrm{MG}$ is targeting of the endplate pathology itself. Theoretically, this would compensate for the blockade and destruction of receptors by pathogenic antibodies. Relevant agents would include those that upregulate synthesis, enhance function, or have neuroprotective effects on endplate proteins. The classic drug used in this way is pyridostigmine, which enhances neuromuscular transmission by inhibition of acetylcholinesterase, thereby prolonging the effects of acetylcholine at the neuromuscular junction. Recently, $\beta 2$ adrenergic receptor agonists have been reported to provide symptomatic benefit in certain forms of congenital myasthenia [150]. The mechanism of action is not entirely clear but is believed to involve stabilization of AChRs at the postsynaptic membrane through protein kinase A (a downstream effector of $\beta 2$ adrenergic receptors). Short-term treatment with the $\beta 2$ adrenergic agonist albuterol was shown to improve weakness in a mouse model of anti-MuSK MG
[151], suggesting that this class of agents might provide benefit in human MuSK MG. 3,4-Diaminopyridine is another symptomatic therapy with potential application in MuSK MG. Exploring use of this drug, which enhances AChR release at the motor nerve terminal, in MuSK MG is supported by preclinical models, experience with congenital MG with MuSK mutations, and case reports [152, 153]. Other endplate targets with potential therapeutic application in $\mathrm{MG}$ include agrin potentiators and positive allosteric modulators of the skeletal muscle AChR [154, 155].

Tirasemtiv is a selective fast skeletal muscle troponin activator. This small molecule binds to skeletal muscle troponin, thereby sensitizing the muscle to calcium and ultimately improving muscle strength under submaximal stimulation [156]. This approach has applications in several neuromuscular diseases, including as a novel symptomatic therapy for MG. A study of tirasemtiv in experimental MG improved grip strength and muscle force after single doses [156]. A small, short-duration, double-blind, randomized, placebo-controlled study in patients with anti-AChR MG showed improvement in the quantitative MG score at $6 \mathrm{~h}$ after 500-mg dosing [157]. Adverse events were generally mild and consistent with studies in healthy volunteers and other patient populations, most notably dizziness. Additional studies are required to demonstrate efficacy in MG and determine optimal dosing conclusively.

\section{Conclusion}

The current standard of care in MG mainly consists of generalized immunosuppression, is not antigen-specific, and is often not even selective in terms of immune cellular targets. The development of new, targeted therapies (based on the immunopathogenesis of MG) may help to improve quality of life in patients who suffer the side effects associated with the chronic use of currently used drugs. Importantly, disease heterogeneity in MG suggests that future therapeutic approaches should be tailored to MG subtype. Accordingly, testing of agents like the ones described should be done in as homogeneous an MG population as possible, which is often a difficult proposition given the relative rarity of the disease. Fortunately, specific targeting of nodes in the immunopathologic pathway, as suggested by the discussion above, will allow for the development of pharmacodynamic biomarkers, which may help to focus and shorten early clinical trials and more effectively identify agents appropriate for later-phase testing. An important caveat is that even focused modulation of the immune system may be associated with risks such as opportunistic infections, reactivation of viral infections, and impaired immune surveillance against malignancy. Thus, close monitoring is essential, and short- and long-term risk 
must always be weighed against potential benefit and prioritized in preclinical and clinical studies.

\section{Compliance with Ethical Standards}

Required Author Forms Disclosure forms provided by the authors are available with the online version of this article.

\section{References}

1. Jayawant S, Parr J, Vincent A. Autoimmune myasthenia gravis. Handb Clin Neurol 2013;113:1465-1468.

2. Meriggioli MN, Sanders DB. Autoimmune myasthenia gravis: emerging clinical and biological heterogeneity. Lancet Neurol 2009;8:475-490

3. Marx A, Porubsky S, Belharazem D, et al. Thymoma related myasthenia gravis in humans and potential animal models. Exp Neurol 2015;270:55-65

4. Marx A, Pfister F, Schalke B, Saruhan-Direskeneli G, Melms A, Ströbel P. The different roles of the thymus in the pathogenesis of the various myasthenia gravis subtypes. Autoimmun Rev 2013;1: 875-884.

5. Reddel SW, Morsch M, Phillips WD. Clinical and scientific aspects of muscle-specific tyrosine kinase-related myasthenia gravis. Curr Opin Neurol 2014;27:558-565.

6. Rødgaard A, Nielsen FC, Djurup R, Somnier F, Gammeltoft S. Acetylcholine receptor antibody in myasthenia gravis: Predominance of IgG subclasses 1 and 3. Clin Exp Immunol 1987;67:82-88

7. Engel AG, Arahata. The membrane attack complex of complement at the endplate in myasthenia gravis. Ann N Y Acad Sci 1987;505:326-332.

8. Drachman DB, Angus CW, Adams RN, Michelson JD, Hoffman GJ. Myasthenic antibodies cross-link acetylcholine receptors to accelerate degradation. N Engl J Med 1978;298:1116-1122.

9. Drachman DB, Adams RN, Josifek LF, Self S. Functional activities of autoantibodies to acetylcholine receptors and the clinical severity of myasthenia gravis. N Engl J Med 1982;307:769-775.

10. Gomez AM, Van Den Broeck J, Vrolix K, et al. Antibody effector mechanisms in myasthenia gravis-pathogenesis at the neuromuscular junction. Autoimmunity 2010;43:353-370.

11. Protti MP, Manfredi AA, Straub C, Howard JF Jr, Conti-Tronconi BM. Immunodominant regions for $\mathrm{T}$ helper-cell sensitization on the human nicotinic receptor alpha subunit in myasthenia gravis. Proc Natl Acad Sci U S A 1990;87:7792-7796.

12. Wang ZY, Okita DK, Howard J Jr, Conti-Fine BM. T-cell recognition of muscle acetylcholine receptor subunits in generalized and ocular myasthenia gravis. Neurology 1998;50:1045-1054.

13. Juel VC, Massey JM. Myasthenia gravis. Orphanet J Rare Dis 2007;2:44.

14. Marx A, Willcox N, Leite MI, et al. Thymoma and paraneoplastic myasthenia gravis. Autoimmunity 2010;43:413-427.

15. Cavalcante P, Cufi P, Mantegazza R, Berrih-Aknin S, Bernasconi P, Le Panse R. Etiology of myasthenia gravis: Innate immunity signature in pathological thymus. Autoimmun Rev 2013;12: 863-874.

16. Sims GP, Shiono H, Willcox N, Stott DI. Somatic hypermutation and selection of B cells in thymic germinal centers responding to acetylcholine receptor in myasthenia gravis. J Immunol 2001;167: 1935-1944.
17. Cavalcante P, Maggi L, Colleoni L, et al. Inflammation and Epstein-Barr virus infection are common features of myasthenia gravis thymus: possible roles in pathogenesis. Autoimmune Dis 2011;2011:213092.

18. Vincent A, Scadding GK, Thomas HC, Newsom-Davis J. In-vitro synthesis of anti-acetylcholine-receptor antibody by thymic lymphocytes in myasthenia gravis. Lancet 1978;1:305-307

19. Meraouna A, Cizeron-Clairac G, Panse RL, et al. The chemokine CXCL13 is a key molecule in autoimmune myasthenia gravis. Blood 2006;108:432-440.

20. Weksler B, Lu B. Alterations of the immune system in thymic malignancies. J Thorac Oncol 2014;9(9 Suppl. 2):S137-S142.

21. Guptill JT, Sanders DB, Evoli A. Anti-MuSK antibody myasthenia gravis: clinical findings and response to treatment in two large cohorts. Muscle Nerve 2011;44:36-40.

22. Cole RN, Reddel SW, Gervasio OL, Phillips WD. Anti-MuSK patient antibodies disrupt the mouse neuromuscular junction. Ann Neurol 2008;63:782-789.

23. Nirula A, Glaser SM, Kalled SL, Taylor FR. What is IgG4? A review of the biology of a unique immunoglobulin subtype. Curr Opin Rheumatol 2011;23:119-124.

24. Leite MI, Strobel P, Jones M, et al. Fewer thymic changes in MuSK antibody-positive than in MuSK antibody-negative MG. Ann Neurol 2005;57:444-448.

25. Della-Torre E, Lanzillotta M, Doglioni C. Immunology of IgG4related disease. Clin Exp Immunol 2015;181:191-206.

26. Yi JS, Guidon A, Sparks S, et al. Characterization of CD4 and CD8 T cell responses in MuSK myasthenia gravis. J Autoimmun 2014;52:130-138.

27. Guptill JT, Yi JS, Sanders DB, et al. Characterization of B Cells in Muscle Specific Kinase Antibody Myasthenia Gravis. Neurol Neuroimmunol Neuroinflamm 2015;2:e77.

28. Zhang B, Tzartos JS, Belimezi M, et al. Autoantibodies to lipoprotein-related protein 4 in patients with double-seronegative myasthenia gravis. Arch Neurol 2012;69:445-451.

29. Shen C, Lu Y, Zhang B, et al. Antibodies against low-density lipoprotein receptor-related protein 4 induce myasthenia gravis. Clin Exp Immunol 2015;181:191-206.

30. Gasperi C, Melms A, Schoser B, et al. Autoantibodies to agrin in myasthenia gravis patients. PLoS One 2014;9:e91816.

31. Romi F, Skeie GO, Gilhus NE, Aarli JA. Striational antibodies in myasthenia gravis. Reactivity and possible clinical significance. Arch Neurol 2005;62:442-446.

32. Gallardo E, Martínez-Hernández E, Titulaer MJ, et al. Cortactin autoantibodies in myasthenia gravis . Autoimmun Rev 2014;13: 1003-1007.

33. Leite MI, Jacob S, Viegas S, et al. IgG1 antibodies to acetylcholine receptors in 'seronegative' myasthenia gravis. Brain 2008;131: 1940-1952.

34. Jacob S, Viegas S, Leite MI, et al. Presence and pathogenic relevance of antibodies to clustered acetylcholine receptor in ocular and generalized myasthenia gravis. Arch Neurol 2012;69: 994-1001.

35. Rodríguez Cruz PM, Al-Hajjar M, Huda S, et al. Clinical features and diagnostic usefulness of antibodies to clustered acetylcholine receptors in the diagnosis of seronegative myasthenia gravis. JAMA Neurol 2015;72:642-649.

36. Grob D, Brunner N, Namba T, Pagala M. Lifetime course of myasthenia gravis. Muscle Nerve 2008;37:141-149.

37. Punga AR, Flink R, Askmark H, Stålberg EV. Cholinergic neuromuscular hyperactivity in patients with myasthenia gravis seropositive for MuSK antibody. Muscle Nerve 2006;34:111-115.

38. Evoli A, Batocchi AP, Palmisani MT, Lo Monaco M, Tonali P. Long-term results of corticosteroid therapy in patients with myasthenia gravis. Eur Neurol 1992;32:37-43. 
39. Pascuzzi RM, Coslett HB, Johns TR. Long-term corticosteroid treatment of myasthenia gravis: report of 116 patients. Ann Neurol 1984;15:291-298.

40. Sgirlanzoni A, Peluchetti D, Mantegazza R, Fiacchino F, Cornelio F. Myasthenia gravis: prolonged treatment with steroids. Neurology 1984;34:170-174.

41. Miller RG, Milner-Brown HS, Mirka A. Prednisone-induced worsening of neuromuscular function in myasthenia gravis. Neurology 1986;36:729-732.

42. Palace J, Newsom-Davis J, Lecky B. A randomized double-blind trial of prednisolone alone or with azathioprine in myasthenia gravis. Myasthenia Gravis Study Group. Neurology 1998;50: 1778-1783.

43. Sanders DB, Evoli A. Immunosuppressive therapies in myasthenia gravis. Autoimmunity 2010;43:428-435.

44. Monden Y, Uyama T, Kimura S, Taniki T. Extrathymic malignancy in patients with myasthenia gravis. Eur J Cancer 1991;27:745.

45. Jones JL, Loftus EV Jr. Lymphoma risk in inflammatory bowel disease: is it the disease or its treatment? Inflamm Bowel Dis 2007;13:1299-1307.

46. Gajdos P, Chevret S, Clair B, et al. Clinical trial of plasma exchange and high-dose intravenous immunoglobulin in myasthenia gravis. Myasthenia Gravis Clinical Study Group. Ann Neurol 1997:41:789-796.

47. Batocchi AP, Evoli A, Dischino C, Tonali P. Therapeutic apheresis in myasthenia gravis. Ther Apher 2000;4:275-279.

48. Zinman L, Ng E, Bril V. IV immunoglobulin in patients with myasthenia gravis: a randomized controlled trial. Neurology 2007;68:837-841.

49. Barth D, Nabavi Nouri M, Ng E, Nwe P, Bril V. Comparison of IVIg and PLEX in patients with myasthenia gravis. Neurology 2011;76:2017-2023.

50. Romi F, Gilhus NE, Aarli JA. Myasthenia gravis: disease severity and prognosis. Acta Neurol Scand Suppl 2006;183:24-25.

51. Gronseth RS, Barohn RJ. Practice parameter: thymectomy for autoimmune myasthenia gravis (an evidence-based review): report of the Quality Standards Subcommittee of the American Academy of Neurology. Neurology 2000;55:7-15.

52. Evoli A, Tonali PA, Padua L, et al. Clinical correlates with antiMuSK antibodies in generalized seronegative myasthenia gravis. Brain 2003;126:2304-2311.

53. Bartoccioni E, Scuderi F, Minicuci GM, Mariano M, Ciaraffa F, Evoli E. Anti-MuSK antibodies: correlation with myasthenia gravis severity. Neurology 2006;67:505-507.

54. Pevzner A, Schoser B, Peters K, et al. Anti-LRP4 autoantibodies in AChR- and MuSK-antibody-negative myasthenia gravis. J Neurol 2012;259:427-435.

55. Felix NJ, Suri A, Salter-Cid L, et al. Targeting lymphocyte costimulation: from bench to bedside. Autoimmunity 2010;43: 514-525.

56. Jung K, Choi I. Emerging co-signaling networks in T cell immune regulation. Immune Netw 2013;13:184-193.

57. Chen L, Flies DB. Molecular mechanisms of T cell co-stimulation and co-inhibition. Nat Rev Immunol 2013;13:227-242.

58. Mueller DL, Jenkins MK, Schwartz RH. Clonal expansion vs functional clonal inactivation: a costimulatory signaling pathway determines the outcome of $\mathrm{T}$ cell antigen receptor occupancy. Annu Rev Immunol 1989;7:445-480.

59. Keating GM. Abatacept: a review of its use in the management of rheumatoid arthritis. Drugs 2013;73:1095-1119.

60. Podojil JR, Miller SD. Targeting the B7 family of co-stimulatory molecules: successes and challenges. BioDrugs 2013;27:1-13.

61. Sandborn WJ, Colombel JF, Sands BE, et al. Abatacept for Crohn's disease and ulcerative colitis. Gastroenterology 2012;143:62-69.
62. Schaffert H, Pelz A, Saxena A, et al. IL-17-producing CD4(+) T cells contribute to the loss of B-cell tolerance in experimental autoimmune myasthenia gravis. Eur J Immunol 2015;45: 1339-1347.

63. Gradolatto A, Nazzal D, Truffault F, et al. Both Treg cells and Tconv cells are defective in the Myasthenia gravis thymus: roles of IL-17 and TNF- $\alpha$. J Autoimmun 2014;52:53-63.

64. Wang XB, Kakoulidou M, Giscombe R, et al. Abnormal expression of CTLA-4 by T cells from patients with myasthenia gravis: effect of an AT-rich gene sequence. J Neuroimmunol 2002;130: 224-232.

65. Renton AE, Pliner HA, Provenzano C, et al. A genome-wide association study of myasthenia gravis. JAMA Neurol 2015;72:396-404

66. Dong C, Nurieva RI. Regulation of immune and autoimmune responses by ICOS. J Autoimmun 2003;21:255-260.

67. Scott BG, Yang H, Tüzün E, Dong C, Flavell RA, Christadoss P. ICOS is essential for the development of experimental autoimmune myasthenia gravis. J Neuroimmunol 2004;153:16-25.

68. Metz DP, Mohn D, Zhang M, et al. Defining dose-response relationships in the therapeutic blockade of B7RP-1-dependent immune responses. Eur J Pharmacol 2009;610:110-118.

69. Ishii N, Takahashi T, Soroosh P, Sugamura K. OX40-OX40 ligand interaction in T-cell-mediated immunity and immunopathology. Adv Immunol 2010;105:63-98.

70. Croft M, So T, Duan W, Soroosh P. The significance of OX40 and OX40L to T-cell biology and immune disease. Immunol Rev 2009;229:173-191.

71. Bhattacharya P, Gopisetty A, Ganesh BB, Sheng JR, Prabhakar BS. GM-CSF-induced, bone-marrow-derived dendritic cells can expand natural Tregs and induce adaptive Tregs by different mechanisms. J Leukoc Biol 2011;89:235-249.

72. Pfender N, Martin R. Daclizumab (anti-CD25) in multiple sclerosis. Exp Neurol 2014;262:44-51.

73. Sakaguchi S. Naturally arising $\mathrm{CD}^{+}$regulatory $\mathrm{T}$ cells for immunologoic self-tolerance and negative control of immune responses. Annu Rev Immunol 2004;22:531-562.

74. Fontenot JD, Rudensky AY. Molecular aspects of regulatory T cell development. Semin Immunol 2004;16:73-80.

75. Seo SJ, Fields ML, Buckler JL, et al. The impact of T helper and T regulatory cells in the regulation of anti-double-stranded DNA B cells. Immunity 2002;16:535-546.

76. Iikuni N, Lourenço EV, Hahn BH, La Cava A. Cutting edge: regulatory $\mathrm{T}$ cells directly suppress B cells in systemic lupus erythematosis. J Immunol 2009;183:1518-1522.

77. Jang E, Cho WS, Cho ML, et al. Foxp3+ regulatory T cells control humoral autoimmunity by suppressing the development of longlived plasma cells. J Immunol 2011;186:1546-1553.

78. Huang YM, Pirskanen R, Giscombe R, Link H, Lefvert AK. Circulating CD4+CD25+ and CD4+CD25+ Tcells in myasthenia gravis and in relation to thymectomy. Scand J Immunol 2004;59: 408-414.

79. Zhang Y, Wang H, Chi L, Wang W. The role of FoxP3+CD4+ CD25hi Tregs in the pathogenesis of myasthenia gravis. Immunol Lett 2009;122:52-57.

80. Masuda M, Matsumoto M, Tanaka S, et al. Clinical implication of peripheral $\mathrm{CD} 4+\mathrm{CD} 25+$ regulatory $\mathrm{T}$ cells and Th17 cells in myasthenia gravis patients. J Neuroimmunol 2010;225:123-131

81. Thiruppathi M, Rowin J, Ganesh B, Sheng JR, Prabhakar BS, Meriggioli MN. Impaired regulatory function in circulating CD4(+)CD25(high)CD127(low/-) T cells in patients with myasthenia gravis. Clin Immunol 2012;145:209-223.

82. Adorini L, Penna G. Dendritic cell tolerance: a key mechanism in immunomodulation by vitamin D receptor agonists. Hum Immunol 2009;70:345-352. 
83. Battaglia M, Stabilini A, Migliavacca B, Horejs-Hoeck J, Kaupper T, Roncarolo MG. Rapamycin promotes expansion of functional $\mathrm{CD} 4+\mathrm{CD} 25+\mathrm{FOXP} 3+$ regulatory T cells of both healthy subjects and type 1 diabetic patients. J Immunol 2006;177:8338-8347.

84. Luther C, Adamopoulou E, Stoeckle C, et al. Prednisolone treatment induces tolerogenic dendritic cells and a regulatory milieu in myasthenia gravis patients. J Immunol 2009;83:841-848.

85. Kessel A, Ammuri H, Peri R, et al. Intravenous immunoglobulin therapy affects $\mathrm{T}$ regulatory cells by increasing their suppressive function. J Immunol 2007;179:5571-5575.

86. Zhu KY, Feferman T, Maiti PK, Souroujon MC, Fuchs S. Intravenous immunoglobulin suppresses experimental myasthenia gravis: immunological mechanisms. J Neuroimmunol 2006;176:187-197.

87. Zhang B, Wu T, Chen M, Zhou Y, Yi D, Guo R. The CD40/CD40L system: a new therapeutic target for disease. Immunol Lett 2013;153:58-61.

88. Im SH, Barchan D, Maiti PK, Fuchs S, Souroujon MC. Blockade of CD40 ligand suppresses chronic experimental myasthenia gravis by down-regulation of Th1 differentiation and upregulation of CTLA-4. J Immunol 2001;166:6893-6898.

89. Kawai T, Andrews D, Colvin RB, Sachs DH, Cosimi AB. Thromboembolic complications after treatment with monoclonal antibody against CD40 ligand. Nat Med 2000;6:114.

90. Pinelli DF, Ford ML. Novel insights into anti-CD40/CD154 immunotherapy in transplant tolerance. Immunotherapy 2015;7: 399-410.

91. de Vos S, Forero-Torres A, Ansell SM, et al. A phase II study of dacetuzumab (SGN-40) in patients with relapsed diffuse large Bcell lymphoma (DLBCL) and correlative analyses of patientspecific factors. J Hematol Oncol 2014;7:44.

92. Okimura K, Maeta K, Kobayashi N, et al. Characterization of ASKP1240, a fully human antibody targeting human CD40 with potent immunosuppressive effects. Am J Transplant 2014;14:1290-1299.

93. de Vos AF, Melief MJ, van Riel D, et al. Antagonist anti-human CD40 antibody inhibits germinal center formation in cynomolgus monkeys. Eur J Immunol 2004;34:3446-3455.

94. Berrih-Aknin S, Le Panse R. Myasthenia gravis: a comprehensive review of immune dysregulation and etiological mechanisms. J Autoimmun 2014;52:90-100.

95. Winkler TH, Waisman A. With a little help from my old T cell: memory follicular $\mathrm{T}$ helper cells driving autoimmunity? Eur J Immunol 2014;44:2869-2871.

96. Luo C, Li Y, Liu W, et al. Expansion of circulating counterparts of follicular helper $\mathrm{T}$ cells in patients with myasthenia gravis. $\mathrm{J}$ Neuroimmunol 2013;256:55-61.

97. Nowak RJ, Dicapua DB, Zebardast N, Goldstein JM. Response of patients with refractory myasthenia gravis to rituximab: a retrospective study. Ther Adv Neurol Disord 2011;4:259-266.

98. Diaz-Manera J, Martinez-Hernandez E, Querol L, et al. Longlasting treatment effect of rituximab in MuSK myasthenia. Neurology 2012;78:189-193.

99. Collongues N, Casez O, Lacour A, et al. Rituximab in refractory and non-refractory myasthenia: a retrospective multicenter study. Muscle Nerve 2012;46:687-691.

100. Yi JS, Decroos EC, Sanders DB, Weinhold KJ, Guptill JT. Prolonged B-cell depletion in MuSK myasthenia gravis following rituximab treatment. Muscle Nerve 2013;48:992-993.

101. Mysler EF, Spindler AJ, Guzman R, et al. Efficacy and safety of ocrelizumab in active proliferative lupus nephritis: results from a randomized, double-blind, phase III study. Expert Opin Investig Drugs 2013;22:1243-1253.

102. Chan AC. Therapeutic antibodies for autoimmunity and inflammation. Nat Rev Immunol 2010;10:301.
103. Tedder TF. B10 cells: a functionally defined regulatory B cell subset. J Immunol 2015;194:1395-1401.

104. Sun F, Ladha SS, Yang L, et al. Interleukin-10 producing-B cells and their association with responsiveness to rituximab in myasthenia gravis. Muscle Nerve 2014;49:487-494.

105. Schneider P, MacKay F, Steiner V, et al. BAFF, a novel ligand of the tumor necrosis factor family, stimulates B cell growth. J Exp Med 1999;189:1747-1756.

106. Ragheb S, Lisak RP. B-cell-activating factor and autoimmune myasthenia gravis. Autoimmune Dis 2011;2011:939520.

107. Ragheb S, Lisak R, Lewis R, Van Stavern G, Gonzales F, Simon $\mathrm{K}$. A potential role for B-cell activating factor in the pathogenesis of autoimmune myasthenia gravis. Arch Neurol 2008;65: 1358-1362.

108. Hahn BH. Belimumab for systemic lupus erythematosus. N Engl J Med 2013;368:1528-1535.

109. Kao D, Lux A, Schwab I, Nimmerjahn F. Targeting B cells and autoantibodies in the therapy of autoimmune diseases. Semin Immunopathol 2014;36:289-299.

110. LeBien TW, Tedder TF. B lymphocytes: how they develop and function. Blood. 2008;112:1570-1580.

111. Neubert K, Meister S, Moser K, et al. The proteasome inhibitor bortezomib depletes plasma cells and protects mice with lupus-like disease from nephritis. Nat Med 2008;14:748-755.

112. Huang Z, Wu Y, Zhou X, et al. Efficacy of therapy with bortezomib in solid tumors: a review based on 32 clinical trials. Future Oncol 2014;10:1795-1807.

113. Verbrugge SE, Scheper RJ, Lems WF, de Gruijl TD, Jansen G. Proteasome inhibitors as experimental therapeutics of autoimmune diseases. Arthritis Res Ther 2015;17:17.

114. Gomez AM, Vrolix K, Martinez-Martinez P, et al. Proteasome inhibition with bortezomib depletes plasma cells and autoantibodies in experimental autoimmune myasthenia gravis. J Immunol 2011;186:2503-2513.

115. Gomez AM, Willcox N, Vrolix K, et al. Proteasome inhibition with bortezomib depletes plasma cells and specific autoantibody production in primary thymic cell cultures from early-onset myasthenia gravis patients. J Immunol 2014;193:1055-1063.

116. Moreau P, Pylypenko H, Grosicki S, et al. Subcutaneous versus intravenous administration of bortezomib in patients with relapsed multiple myeloma: a randomised, phase 3, non-inferiority study. Lancet Oncol 2011;12:431-440.

117. Bringhen S, Larocca A, Rossi D, et al. Efficacy and safety of onceweekly bortezomib in multiple myeloma patients. Blood 2010;116:4745-4753.

118. Pincetic A, Bournazos S, DiLillo DJ, et al. Type I and type II Fc receptors regulate innate and adaptive immunity. Nat Immunol 2014; 15:707-716.

119. Kaneko Y, Nimmerjahn F, Ravetch JV. Anti-inflammatory activity of immunoglobulin $\mathrm{G}$ resulting from Fc sialylation. Science 2006;313:670-673.

120. Nagelkerke SQ, Kuijpers TW. Immunomodulation by IVIg and the role of $\mathrm{Fc}$-gamma receptors: classic mechanisms of action after all? Front Immunol 2015;5:674.

121. Thiruppathi M, Sheng JR, Li L, Prabhakar BS, Meriggioli MN. Recombinant IgG2a Fc (M045) multimers effectively suppress experimental autoimmune myasthenia gravis. J Autoimmun 2014;52:64-73.

122. Challa DK, Velmurugan R, Ober RJ, Sally Ward E. FcRn: from molecular interactions to regulation of IgG pharmacokinetics and functions. Curr Top Microbiol Immunol 2014;382:249-272.

123. Liu L, Garcia AM, Santoro H, Zhang Y, McDonnell K, Bitoni A. Amelioration of experimental autoimmune myasthenia gravis in rats by neonatal FcR blockade. J Immunol 2007;178:5390-5398.

124. Horton HM, Chu SY, Ortiz EC, et al. Antibody-mediated coengagement of $\mathrm{Fc} \gamma \mathrm{RIIb}$ and $\mathrm{B}$ cell receptor complex 
suppresses humoral immunity in systemic lupus erythematosus. J Immunol 2011;186:4223-4233.

125. Alexion. Pharmaceuticals Inc. Soliris. Eculizumab prescribing information. 2014

126. Sahashi K, Engel AG, Linstrom JM, Lambert EH, Lennon VA. Ultrastructural localization of immune complexes (IgG and C3) at the end-plate in experimental autoimmune myasthenia gravis. J Neuropathol Exp Neurol 1978;37:212-223.

127. Lennon VA, Seybold ME, Lindstrom JM, Cochrane C, Ulevitch R. Role of complement in the pathogenesis of experimental autoimmune myasthenia gravis. J Exp Med 1978;147:973-983.

128. Nakano S, Engel AG. Myasthenia gravis: quantitative immunocytochemical analysis of inflammatory cells and detection of complement membrane attack complex at the end-plate in 30 patients. Neurology 1993;43:1167-1172.

129. Nielsen FC, Rodgaard A, Djurup R, Somnier F, Gammeltoft S. A triple antibody assay for the quantitation of plasma IgG subclass antibodies to acetylcholine receptors in patients with myasthenia gravis. J Immunol Methods 1985;83:249-258.

130. Rodgaard A, Nielsen FC, Djurup R, Somnier F, Gammeltoft S. Acetylcholine receptor antibody in myasthenia gravis: predominance of IgG subclasses 1 and 3. Clin Exp Immunol 1987;67:82-88.

131. Howard JF, Jr., Barohn RJ, Cutter GR, et al.; MG Study Group. A randomized, double-blind, placebo-controlled phase II study of eculizumab in patients with refractory generalized myasthenia gravis. Muscle Nerve 2013;48:76-84.

132. Bauer E, Lucier J, Furst DE. Brodalumab — an IL-17RA monoclonal antibody for psoriasis and psoriatic arthritis. Expert Opin Biol Ther 2015;15:883-893.

133. Dyring-Andersen B, Skov L, Zachariae C. Ixekizumab for treatment of psoriasis. Expert Rev Clin Immunol 2015;11:435-442.

134. Bao Y, Cao X. The immune potential and immunopathology of cytokine-producing B cell subsets: a comprehensive review. J Autoimmun 2014;55:10-23.

135. Deng C, Goluszko E, Tüzün E, Yang H, Christadoss P. Resistance to experimental autoimmune myasthenia gravis in IL-6-deficient mice is associated with reduced germinal center formation and $\mathrm{C} 3$ production. J Immunol 2002;169:1077-1083.

136. Aricha R, Mizrachi K, Fuchs S, Souroujon MC. Blocking of IL-6 suppresses experimental autoimmune myasthenia gravis. J Autoimmun 2011;36:135-141.

137. Ogata A, Amano K, Dobashi H, et al.; MUSASHI Study Investigators. Longterm safety and efficacy of subcutaneous tocilizumab monotherapy: results from the 2-year open-label extension of the MUSASHI study. J Rheumatol 2015;42:799-809.

138. Alten R, Maleitzke T. Tocilizumab: a novel humanized antiinterleukin 6 (IL-6) receptor antibody for the treatment of patients with non-RA systemic, inflammatory rheumatic diseases. Ann Med 2013;45:357-363.

139. Araki M, Matsuoka T, Miyamoto K, et al. Efficacy of the anti-IL-6 receptor antibody tocilizumab in neuromyelitis optica: a pilot study. Neurology 2014;82:1302-1306.

140. Bhattacharya P, Thiruppathi M, Elshabrawy HA, Alharshawi K, Kumar P, Prabhakar BS. GM-CSF: an immune modulatory cytokine that can suppress autoimmunity. Cytokine 2015.

141. Sheng JR, Li L, Ganesh BB, Vasu C, Prabhakar BS, Meriggioli MN. Suppression of experimental autoimmune myasthenia gravis by granulocyte-macrophage colony-stimulating factor is associated with an expansion of FoxP3+ regulatory $\mathrm{T}$ cells. $\mathrm{J}$ Immunol 2006;177:5296-5306.

142. Sheng JR, Li LC, Ganesh BB, Prabhakar BS, Meriggioli MN. Regulatory T cells induced by GM-CSF suppress ongoing experimental myasthenia gravis. Clin Immunol 2008;128:172-180.

143. Sheng JR, Muthusamy T, Prabhakar BS, Meriggioli MN. GMCSF-induced regulatory $\mathrm{T}$ cells selectively inhibit antiacetylcholine receptor-specific immune responses in experimental myasthenia gravis. J Neuroimmunol 2011;240-241:65-73.

144. Thiruppathi M, Rowin J, Li Jiang Q, Sheng JR, Prabhakar BS, Meriggioli MN. Functional defect in regulatory T cells in myasthenia gravis. Ann N Y Acad Sci 2012;1274:68-76.

145. Rowin J, Thiruppathi M, Arhebamen E, Sheng J, Prabhakar BS, Meriggioli MN. Granulocyte macrophage colony-stimulating factor treatment of a patient in myasthenic crisis: effects on regulatory T cells. Muscle Nerve 2012;46:449-453.

146. Paas-Rozner M, Dayan M, Paas Y, et al. Oral administration of a dual analog of two myasthenogenic T cell epitopes down-regulates experimental autoimmune myasthenia gravis in mice. Proc Natl Acad Sci U S A 2000;97:2168-2173.

147. Shi FD, Bai XF, Xiao BG, van der Meide PH, Link H. Nasal administration of multiple antigens suppresses experimental autoimmune myasthenia gravis, encephalomyelitis and neuritis. $\mathbf{J}$ Neurol Sci 1998;155:1-12.

148. Luo J, Lindstrom J. Antigen-specific immunotherapeutic vaccine for experimental autoimmune myasthenia gravis. J Immunol 2014;193:5044-5055.

149. Passweg J, Tyndall A. Autologous stem cell transplantation in autoimmune diseases. Semin Hematol 2007;44:278-285.

150. Liewluck T, Selcen D, Engel AG. Beneficial effects of albuterol in congenital endplate acetylcholinesterase deficiency and Dok-7 myasthenia. Muscle Nerve 2011;44:789-794.

151. Ghazanfari N, Morsch M, Tse N, Reddel SW, Phillips WD. Effects of the $\beta 2$-adrenoceptor agonist albuterol in a mouse model of antiMuSK myasthenia gravis. PLoS One 2014;9:e87840.

152. Morsch M, Reddel SW, Ghazanfari N, Toyka KV, Phillips WD. Pyridostigmine but not 3,4-diaminopyridine exacerbates ACh receptor loss and myasthenia induced in mice by muscle-specific kinase autoantibody. J Physiol 2013;591:2747-2762.

153. Skjei KL, Lennon VA, Kuntz NL. Muscle specific kinase autoimmune myasthenia gravis in children: a case series. Neuromuscul Disord 2013;23:874-882.

154. Ngo ST, Cole RN, Sunn N, Phillips WD, Noakes PG. Neuregulin1 potentiates agrin-induced acetylcholine receptor clustering through muscle-specific kinase phosphorylation. J Cell Sci 2012;125:1531-1543.

155. Spurny R, Debaveye S, Farinha A, et al. Molecular blueprint of allosteric binding sites in a homologue of the agonist-binding domain of the $\alpha 7$ nicotinic acetylcholine receptor. Proc Natl Acad Sci U S A 2015;112:E2543-E2552.

156. Russell AJ, Hartman JJ, Hinken AC, et al. Activation of fast skeletal muscle troponin as a potential therapeutic approach for treating neuromuscular diseases. Nat Med 2012;18:452-455.

157. Sanders DB, Rosenfeld J, Dimachkie MM, Meng L, Malik FI; Tirasemtiv in Myasthenia Gravis Study Group. A double-blinded, randomized, placebo-controlled trial to evaluate efficacy, safety, and tolerability of single doses of tirasemtiv in patients with acetylcholine receptor-binding antibody-positive myasthenia gravis. Neurotherapeutics 2015;12:455-456. 